\title{
Do Preconditions of Inflation Targeting Framework Matter?
}

\author{
Syed Imran Ali Meerza ${ }^{1}$ \\ ${ }^{1}$ Department of Agriculture, Arkansas Tech University, United States \\ Correspondence: Syed Imran Ali Meerza, Department of Agriculture, Arkansas Tech University, United States. \\ E-mail: smeerza@atu.edu
}

Received: February 28, 2020

Accepted: March 26, 2020

Online Published: April 12, 2020

doi:10.5539/ijef.v12n5p51

URL: https://doi.org/10.5539/ijef.v12n5p51

\begin{abstract}
The main feature of inflation targeting (IT) framework is the public announcement by the central bank that it will keep inflation at a numerical inflation target. A large literature addresses preconditions that a country should satisfy before adopting IT. However, there is much debate about whether satisfying these preconditions are essential. This study addresses this debate. Empirical results indicate that the fulfillment of preconditions before IT adoption ensures effective implementation of IT in the short-run. However, countries that met all preconditions before IT adoption do not have an advantage over countries that didn't meet all preconditions before IT adoption in the long-run.
\end{abstract}

Keywords: inflation, monetary policy

JEL Classifications: E20.

\section{Introduction}

High inflation is costly because it leads an economy to allocate resources inefficiently; it also increases uncertainty. For this reason, how the central bank deals with inflation affect the overall performance of the economy. Over the last twenty-four years, monetary policy frameworks design to keep inflation within a predefined target range have become increasingly popular. In an inflation targeting (IT) framework, the central bank announces publicly its official quantitative targets or target ranges for the inflation rate at one or more-time horizons and acknowledges explicitly low and stable inflation as its long-run primary objective of monetary policy. An IT framework was first introduced in New Zealand in 1990. New Zealand experienced high inflation in the 1970s and early 1980s. The Reserve Bank of New Zealand introduced the Reserve Bank of New Zealand Act (RBNZA) in 1989 to ensure low and stable inflation. Murray (2006) points out that when IT was implemented in New Zealand, it was considered a special case. However, one year later, the Bank of Canada announced it was following New Zealand; and the economic profession's reaction to the framework changed. Many countries have adopted IT since 1990. As of 2015, 26 countries have adopted inflation targeting; 14 of these countries are developed, and 16 of these are developing (Note 1).

The benefits of IT have been extensively investigated in the last few decades. For developed countries, Mollick et al. (2011), Mishkin and Schimidt (2007), Newman and Von Hagen (2002), and Debelle (1999) show that adopting an IT framework is associated with low average inflation, a rise in economic growth and reduced impacts of supply shocks on prices and economic activity more generally. However, Ball and Sheridan (2005) find no evidence that adopting an IT framework has a significant positive impact on economic performance.

A large literature addresses the preconditions that a country must fulfill before it adopts an IT framework. According to Mishkin (2000), a country must meet five preconditions for an inflation-targeting framework to be successful. Specifically, the central bank must publicly announce numerical inflation targets, identify price stability as the primary goal of monetary policy, adopt an information-based strategy where all information regarding different variables can be used to forecast future movements of inflation, operate transparently and be held accountable for its policy decisions and outcomes.

Studies of preconditions uniformly emphasize institutional independence. According to Islam and Uddin (2011), central bank independence plays a vital role in the successful introduction of IT. The central bank also requires data and well-developed modeling capabilities for predicting future inflation. This is because IT is a forward-looking framework (Aliyu \& Englama, 2009; and Batini \& Laxton, 2006). In addition, Aliyu and Englama (2009), Tutar (2002) and Christoffersen et al. (2001) find that stable and predictable relationship 
between monetary policy instruments and the inflation rate is a key precondition of an IT framework. Without a stable and predictable relationship between monetary policy instruments and inflation, it is challenging for the central bank to achieve its inflation target. The central bank must change monetary policy decisions on the basis of forecasted changes in inflation. So, the central bank requires the data and the forecasting models to predict future movements of inflation. Moreover, to predict the future movements of inflation efficiently, policymakers must have access to those monetary policy instruments that can effectively influence macroeconomic variables. In addition, capital, money and foreign exchange markets must respond quickly to the change in monetary policy instruments. If these markets do not respond quickly to the change in monetary policy instruments, the effectiveness of monetary policy instruments is reduced. As a result, these monetary policy instruments will have little impact on inflation variability.

Agenor (2002) and Khan (2003) emphasize the importance of preconditions for successful implementation of inflation targeting. On the other hand, Truman (2003) and Batini and Laxton (2006) conclude that the preconditions of IT should be considered as desirable not essential. The authors do not find any evidence to support the view that satisfying preconditions before adopting IT is highly correlated with improved economic performance. Debelle (2001) and Carare et al. (2002) express relatively neutral views on the importance of preconditions. In summary, there are contradicting views on whether a country must meet preconditions before IT adoption. This study addresses this debate. I consider seventeen IT and eighteen non-IT countries, all of which I list in Table 1.

Table 1. List of IT and non-IT countries

\begin{tabular}{ll}
\hline IT countries & Brazil, Canada, Chile, Columbia, Czech Republic, Hungary, Mexico, New Zealand, Norway Peru, \\
& Philippines, Poland, South Africa, South Korea, Sweden, Switzerland and United Kingdom \\
\hline Non-IT countries & $\begin{array}{l}\text { Austria, Bolivia, Denmark, Estonia, France, Germany, Italy, Japan, Lithuania, Malaysia, } \\
\text { Netherlands, Portugal, Russia, Singapore, Slovenia, Spain, United States and Venezuela }\end{array}$ \\
\hline
\end{tabular}

Currently, inflation in many least developed countries, especially in Asia and Latin America, is high. The central banks of these countries look to introduce IT frameworks to ensure low and stable inflation. International donor agencies such as World Bank (WB), Asian Development Bank (ADB) and International Monetary Fund (IMF) recommend that these least developed countries should satisfy the preconditions of IT before adopting it. For this reason, the results of this study will be important for those least developed countries deciding whether, when and how best to implement an IT framework.

This study examines both the short-run and long-run effects of preconditions of IT on post-IT macroeconomic performance. Specific objectives of this research work are as follows: to find out whether the countries met preconditions of an IT framework before adopting this policy, and to assess the role of preconditions of an IT framework on post-IT macroeconomic performance. Based on our review of the literature on preconditions of IT, I determine the following preconditions are most essential: central bank independence (CBI), inflation forecasting and modeling capabilities of the central bank, and the existence of a stable and predictable relationship between monetary policy instruments and the inflation rate. However, I include only two of these in our study: CBI and the existence of a stable and predictable relationship between monetary policy instruments and the inflation rate. I do not include the modeling capabilities of the central bank because I cannot measure this precondition without surveying the central banks of IT countries - an effort that I leave for future research (Note 2).

\section{Research Design}

\subsection{Central Bank Independence}

To measure the degree of CBI, I use a CBI index in Cukierman et al. (1992). Cukierman's indices are based on legal aspects of independence and the turnover rate of central bank governors. The values of all indices range from 0 to 1. I use Cukierman's legal index as a measure of CBI. For the legal index, higher values indicate greater degrees of CBI. Recent studies, including Batini and Laxton (2006), Jacome and Vazquez (2005), Crowe and Meade (2007), Dreher et al. (2008), and Siklos (2008) have used Cukierman's legal index to measure the degree of CBI.

\subsection{Relationship between Monetary Policy Instruments and Inflation}

To measure the relationship between monetary policy instruments and inflation, I use the Toda Yamamoto Granger causality test to find out whether a country had a stable and predictable relationship between monetary 
instruments and inflation before IT adoption. On the basis of the Toda Yamamoto Granger causality tests of thirty-five countries, I code a dummy variable for this precondition which is a major contribution of this study. As a result, I include this precondition along with a CBI index as independent variables in our regression analyses to measure the effects of preconditions on post IT macroeconomic performance.

Specifically, I use a VAR based Granger causality test. I use the unit root test to identify the order of integration, which is, in some cases, ambiguous. To address this ambiguity, I follow the methodology of Star (2005), who uses the Toda Yamamoto Granger causality test. The Toda Yamamoto Granger causality test does not require that variables in the model share a particular order of integration. These test results reveal whether policy variables, either individually or jointly, can explain future movements of inflation. I assign a dummy-variable value of one to a country if at least one policy variable of that country can explain future movements of inflation. Otherwise, I assign a dummy-variable value of zero. And, I include this dummy variable as an independent variable in regression analyses to determine the effects of this precondition on post-IT macroeconomic performance.

I use four unit root tests to check the stationarity of the variables. The Augmented Dicky Fuller (ADF) and Phillips-Perron (P-P) tests are traditional unit root tests that are best for long time series. Because, I use short time series, I also use a modified version of the Dicky-Fuller (D-F) test based on the generalized least square (GLS) method. I also use the Kwiathowski, Phillips, Schmidt and Shin (KPSS) test, because the null hypothesis of KPSS is opposite the null hypothesis of the ADF, P-P and DF-GLS tests. As a result, the KPSS allows us to cross check the results of the other unit root tests.

An n-equation and $n$-variable vector autoregression is a system of equations in which each variable is explained by lagged observations of the $\mathrm{n}$ number of variables in the system. I do not include exogenous variables as regressands in our VAR analysis. A VAR for an $(\mathrm{N} \times 1)$ wide stationary stochastic process, $Y_{t}$, can be expressed as:

$$
Y_{t}=\sum_{j=1}^{k} A_{j}^{k} Y_{t-j}+\gamma_{t}^{k}
$$

where, $A_{j}^{k}$ represents $(\mathrm{N} \times \mathrm{N})$ matrices and $\gamma_{t}^{k}$ represents $\mathrm{N} \times 1$ stochastic error process. $Y_{t}$ includes $t=1,2, \ldots ., T$ observations of each variables. Here, $j=1,2, \ldots \ldots k$ and $\mathrm{k}$ indicates the number of lags in the VAR.

I use four variables VAR with $\mathrm{k}$ lags. I include following variables: the consumer price index (cpi), the money supply ( $m s$ ), the interest rate (int) and the exchange rate (ex). Thus, the VAR can be expressed as equation 2:

$$
\left[\begin{array}{c}
c p i_{t} \\
m s_{t} \\
\text { int }_{t} \\
\text { ex }_{t}
\end{array}\right]=\left[\begin{array}{l}
\delta_{1} \\
\delta_{2} \\
\delta_{3} \\
\delta_{4}
\end{array}\right]+\sum_{j=1}^{k}\left[\begin{array}{l}
\beta_{11, j} \beta_{12, j} \beta_{13, j} \beta_{14, j} \\
\beta_{21, j} \beta_{22, j} \beta_{23, j} \beta_{24, j} \\
\beta_{31, j} \beta_{32, j} \beta_{33, j} \beta_{34, j} \\
\beta_{41, j} \beta_{42, j} \beta_{43, j} \beta_{44, j}
\end{array}\right]\left[\begin{array}{l}
c p i_{t-j} \\
m s_{t-j} \\
i n t_{t-j} \\
e x_{t-j}
\end{array}\right]+\left[\begin{array}{l}
e_{1 t} \\
e_{2 t} \\
e_{3 t} \\
e_{4 t}
\end{array}\right]
$$

where $\delta_{1}, \delta_{2}, \delta_{3}$ and $\delta_{4}$ are constants. $\mathrm{N}=4$ variables with $\mathrm{k}$ number of lags each. There are four systems of equations and the right-hand side of each system of equations includes the same variables and the same number of lags. The Toda Yamamoto Granger causality test is appropriate regardless of whether time series are integrated with different orders. According to Toda and Yamamoto (1995), Toda Yamamoto test is artificially augment the correct VAR order $\mathrm{k}$ by the maximum order of integration, say d. So, $k+d$ order of VAR is estimated although the coefficients of these extra $d$ lags are not included.

$$
\left[\begin{array}{c}
c p i_{t} \\
m s_{t} \\
\text { int }_{t} \\
\text { ext }
\end{array}\right]=\left[\begin{array}{l}
\delta_{1} \\
\delta_{2} \\
\delta_{3} \\
\delta_{4}
\end{array}\right]+\sum_{j=1}^{k}\left[\begin{array}{l}
\beta_{11, j} \beta_{12, j} \beta_{13, j} \beta_{14, j} \\
\beta_{21, j} \beta_{22, j} \beta_{23, j} \beta_{24, j} \\
\beta_{31, j} \beta_{32, j} \beta_{33, j} \beta_{34, j} \\
\beta_{41, j} \beta_{42, j} \beta_{43, j} \beta_{44, j}
\end{array}\right]\left[\begin{array}{l}
c p i_{t-j} \\
m s_{t-j} \\
i n t_{t-j} \\
e x_{t-j}
\end{array}\right]+\sum_{i=k+1}^{d}\left[\begin{array}{l}
\beta_{11, i} \beta_{12, i} \beta_{13, i} \beta_{14, i} \\
\beta_{21, i} \beta_{22, i} \beta_{23, i} \beta_{24, i} \\
\beta_{31, i} \beta_{32, i} \beta_{33, i} \beta_{34, i} \\
\beta_{41, i} \beta_{42, i} \beta_{43, i} \beta_{44, i}
\end{array}\right]\left[\begin{array}{c}
c p i_{t-i} \\
m s_{t-i} \\
i n t_{t-i} \\
e x_{t-i}
\end{array}\right]+\left[\begin{array}{c}
e_{1 t} \\
e_{2 t} \\
e_{3 t} \\
e_{4 t}
\end{array}\right]
$$

The Toda Yamamoto test uses equation 3 instead of equation 2. To test for Granger causality with the Toda Yamamoto method does not require a cointegration test or a transformation of the VAR into an error correction model. However, it is important to employ the unit root test and model selection criteria to identify $d$ and $k$ respectively before testing for Granger causality.

\subsection{Effects of Preconditions of IT on Macroeconomic Performance}

To determine the effects of preconditions on the post-IT macroeconomic performance of IT, I specify the following model: 


$$
Y_{\text {post }}^{j}-Y_{\text {pre }}^{j}=\alpha+\beta_{1} C B I+\beta_{2} P S R+\beta_{3}(C B I * P S R)+\varepsilon
$$

where, $Y_{\text {pre }}^{j}$ and $Y_{\text {post }}^{j}$ represent values of macroeconomic indicator $j$ before and after adopting IT, respectively. $C B I$ represents the central bank independence index, and $P S R$ is a dummy variable where I include value 1 if a stable and predictable relationship between monetary policy instruments and inflation existed before adopting IT; I include 0 otherwise. I also include the interaction term CBI*PSR. $\alpha$ is a constant, and $j$ represents the particular macroeconomic-performance indicator. $\beta_{1}, \beta_{2}$ and $\beta_{3}$ are coefficients, and $\varepsilon$ is an error term. To begin, I estimate this regression for IT countries only. Our sample includes seventeen of IT countries. For the dependent variables, I consider the following macroeconomic indicators: growth, growth volatility, inflation and inflation volatility. I estimate two regression equations for each economic indicator; the first regression includes five years before and after IT adoption; the second regression includes ten years before and after IT adoption. The real GDP growth rate and the standard deviation of the real GDP growth rate represent output growth and output growth volatility, respectively. I use the percentage change in the consumer price index (CPI) as a measurement of inflation and the standard deviation of the percentage change in CPI as a measure of inflation volatility. Then, I estimate this regression with a control group of non-IT countries. I specify this regression model in equation 6. I estimate two regression equations, as I did earlier, for each economic indicator.

$$
Y_{\text {post }}^{j}-Y_{\text {pre }}^{j}=\alpha+\beta_{1} C B I+\beta_{2} P S R+\beta_{3} I T+\beta_{4}(C B I * I T)+\beta_{5}(P S R * I T)+\beta_{6}(C B I * P S R * I T)+\varepsilon
$$

where, the interaction terms $C B I * I T$ and $P S R * I T$ represent impacts of $C B I$ and $I T$, and, PSR and IT, together on macroeconomic performance. I also include interaction term $C B I * P S R * I T$.

Cecchetti and Ehrmann (2000) estimate inflation variability and output variability five years before and after IT adoption. They argue that adopting an IT framework is likely to increase output variability and reduce inflation variability if a country is operating on a single inflation-output variability frontier. Intuitively, they show that using inflation variability and output variability data before and after adopting IT may provide misleading results. They argue that both output and inflation variability fall if the economy experiences smaller supply shocks after IT than before. To address this issue, Ceccehetti et al. (2002) specify the following economic model, which I reproduce here in equations 7 through 9 .

$$
L=E\left[\alpha\left(\pi-\pi^{\text {trend }}\right)^{2}+(1-\alpha)\left(y-y^{\text {trend }}\right)^{2}\right]
$$

where $\pi$ is inflation, $y$ is the log of aggregate output, $\pi^{\text {trend }}$ is desired level inflation, $y^{\text {trend }}$ is the desired level of output, and $E$ is the mathematical expectation. The value of $\alpha$ in equation (7) represents the weight the central bank assigns to inflation variability. The value of $\alpha$ ranges from 0 to 1 ; presumably, an IT central bank has a relatively high value of $\alpha$. This loss function only includes output and inflation, and it implies a trade-off between output variability and inflation variability. According to Ceccehetti et al. (2002), it is not possible to solve the policymakers' problem without understanding the constraints the policymakers face. These constraints include the dynamics of inflation and output and their relationships with the interest rate. Ceccehetti et al. (2002) specify these relationships in the following way:

$$
\begin{gathered}
y_{t}=-\gamma\left(r_{t}-d_{t}\right)+s_{t} \quad \gamma<0 \\
\pi_{t}=-\left(r_{t}-d_{t}\right)-\omega s_{t}
\end{gathered}
$$

where, $d_{t}$ and $s_{t}$ present aggregate demand and aggregate supply shocks, respectively. $1 / \gamma$ represents the slope of aggregate supply, while $\omega$ represents the slope of aggregate demand. The central bank solves the loss function subject to these constraints. The solution to this minimization problem yields the following:

$$
\frac{\sigma_{y}^{2}}{\sigma_{\pi}^{2}}=\left[\frac{\alpha}{\gamma(\alpha-1)}\right]^{2}
$$

where, $\frac{\sigma_{y}^{2}}{\sigma_{\pi}^{2}}$ represents the ratio of output variability to inflation variability. The value of $\alpha$ ranges from 0 to 1 , and it determines the economy's position on the output-inflation variability frontier. In figure 1, I represent two hypothetical inflation-output variability frontiers. The darker line corresponds to a flat aggregate supply curve (and, so, a relatively high value of $\gamma$ ). On the other hand, the lighter line corresponds to a steep aggregate supply curve (and, thus, a relatively low value of $\gamma$ ). If the central bank increases the value of $\alpha$ (the measure of the 
central bank's aversion to inflation), the economy will move northwest along the inflation-output variability frontier. The tradeoff between inflation and output is higher if the aggregate supply curve is flatter.

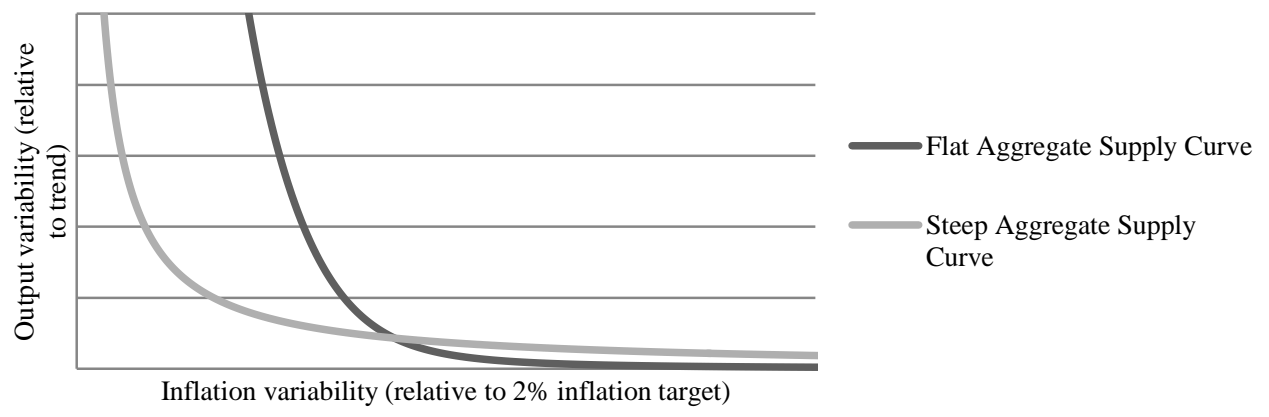

Figure 1. Inflation-output variability tradeoff

So, I follow Ceccehetti et al. (2002), and I measure, for each country, the ratio of output-inflation variability for five years before and after adopting IT. I also estimate the ratio of output-inflation variability for ten years before and after adopting IT. I assume that aggregate demand and aggregate supply slopes are constant before and after IT. As a result, the dependent variable in equation (11) reflects the behavior of $\alpha$, because according to Equation 10, the output-inflation variability ratio and $\alpha$ rise and fall together. I estimate the following regression model:

$$
\begin{gathered}
\frac{\frac{\sigma_{y, p o s t}^{2}}{\sigma_{\pi, p o s t}^{2}}}{\frac{\sigma_{y, p r e}^{2}}{\sigma_{\pi, p r e}^{2}}}=\alpha+\beta_{1} C B I+\beta_{2} P S R+\beta_{3} I T+\beta_{4}(C B I * I T)+\beta_{5}(P S R * I T)+\beta_{6}(C B I * P S R * I T)+ \\
\beta_{7} \text { Dev }+\beta_{8}(\operatorname{Dev} * I T)+\varepsilon
\end{gathered}
$$

where, $\frac{\sigma_{y, p o s t}^{2}}{\sigma_{\pi, p o s t}^{2}}$ and $\frac{\sigma_{y, p r e}^{2}}{\sigma_{\pi, p r e}^{2}}$ represent the post and pre output-inflation variability ratio respectively. I include Dev as a dummy variable that takes the value 1 for developing countries and 0 otherwise. I also include $D e v * I T$ as an interaction term that estimates the impact of $D e v$ and $I T$ together. I use a real GDP index as the measure of output and the percentage change in CPI as the measure of inflation (Note 3).

\section{Results and Discussions}

\subsection{Preconditions of IT and Their Measurements}

I collect Cukierman's CBI index for thirty-five countries from Polillo and Guillén (2005). For IT countries, I collect the CBI index for the year before IT is adopted. Of course, the non-IT countries (the control group) do not have IT adoption dates. Gemayel et al. (2011), use the average adoption year to partition the time period of non-IT countries. I do not follow this approach, because if I do, I must exclude European Union (EU) member countries such as Austria, Germany, France, Italy, and Spain; data for these countries are available only up to 1998. Specifically, the money supply data for these countries are not available from 1999, when the EU adopted a common currency. So, I partition non-IT countries in 1993 (see Table 2) (Note 4).

Table 2. List of IT and non-IT countries with the year before IT is adopted

\begin{tabular}{cccc}
\hline IT Country & Year before IT is adopted & Non-IT Country & Partition year of non-IT \\
\hline Brazil & 1998 & Austria & 1993 \\
Canada & 1990 & Bolivia & 2000 \\
Chile & 1998 & Denmark & 1993 \\
Columbia & 1998 & Estonia & 2000 \\
Czech Republic & 1996 & France & 1993 \\
Hungary & 2000 & Germany & 1993 \\
Mexico & 2000 & Italy & 1993 \\
New Zealand & 1989 & Japan & 1993 \\
Norway & 2000 & Lithuania & 2000 \\
\hline
\end{tabular}




\begin{tabular}{cccc}
\hline Peru & 2001 & Malaysia & 1993 \\
Philippines & 2001 & Netherlands & 1993 \\
Poland & 1997 & Portugal & 1993 \\
South Africa & 1999 & Russia & 2000 \\
South Korea & 2000 & Singapore & 2000 \\
Switzerland & 1999 & Slovenia & 2000 \\
Sweden & 1992 & Spain & 1993 \\
United Kingdom & 1991 & United States & 1993 \\
-- & -- & Venezuela & 2000 \\
\hline
\end{tabular}

In Figures 2 and 3, I illustrate the CBI index for IT and non-IT countries before the adoption/partition year. Poland had the highest CBI index before adopting IT among seventeen IT countries. On the other hand, Norway had the lowest CBI index before adopting IT. Among the non-IT countries, Spain had the highest CBI index, and Japan had the lowest CBI index before the partition year. The average CBI index of IT countries before adopting IT is 0.49 . In contrast, the average CBI index of non-IT countries before the partition year is 0.58 .

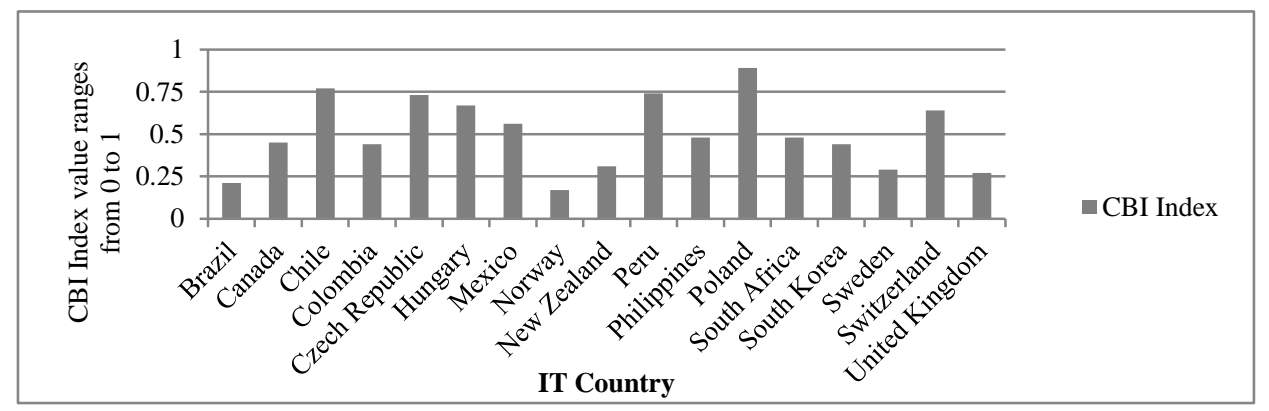

Figure 2. CBI index of IT countries in the year before IT is adopted

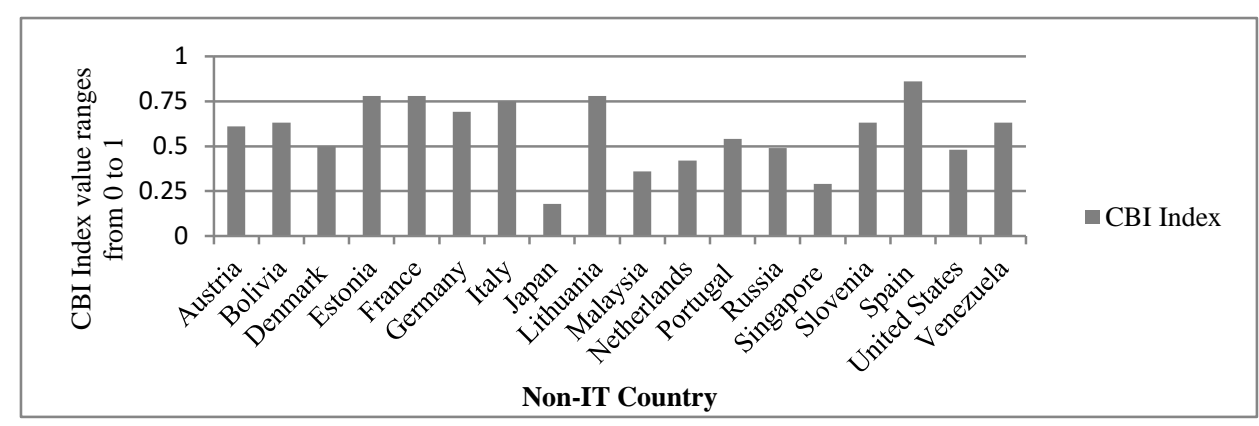

Figure 3. CBI index of non-IT countries in the year before the partition

\subsection{Existence of Stable and Predictable Relationship between Monetary Policy Instruments and Inflation}

To determine the relationship between policy instruments and inflation variability before the adopting/partition year, I use the Granger causality test to determine the Granger effects of monetary policy instruments on inflation. For IT countries, the sample period for the Granger causality tests is six years (seventy-two months) before the central bank adopts IT (Note 5). Similarly, for all non-IT countries except Estonia, Lithuania, Russia, Singapore, and Venezuela, the sample period for the Granger causality tests is six years (seventy-two months) before the partition year (Note 6). In most cases, the data source for the industrial production index (IPI), the consumer price index (CPI), the M1 money supply, the M2 money supply, the interest rate, and the exchange rate is International Financial Statistics (IFS) of the International Monetary Fund (IMF) (Note 7). Additionally, when data are not available in IFS, I collect the data from the Organization for Economic Cooperation and Development (OECD) and the Reserve Bank of New Zealand (detail information about variables, data sources, and time period are available in Appendix Table A1) (Note 8).

It is not possible to select in advance which monetary policy variable or variables are correlated with inflation. For this reason, I include three monetary policy variables in VAR: the money supply, the interest rate and the real effective exchange rate. Variables M1 and M2 represent possible money supply instruments, and money market 
interest rate represents a possible interest rate instrument. Again, I use the percentage change in the consumer price index (CPI) as the measure of inflation. I use monthly data. All data are in natural logs and seasonally adjusted. The monthly data of M2 money supply for Austria, Chile and the United Kingdom are not available for the required sample period (see Table 3). The monthly data of M1 money supply for Czech Republic, Italy, Netherland, New Zealand, Norway, Poland, Russia, Spain and Sweden are not available for the required sample period. So, I include only M1 money supply in the VAR for Austria, Chile and the United Kingdom. Likewise, I include only M2 money supply in the VAR for the Czech Republic, Italy, the Netherlands, New Zealand, Norway, Poland, Russia and Spain (Note 9).

In order to avoid less power issue of traditional unit root tests, I follow Starr (2005), and I include four different types of unit root tests: the ADF, P-P, DF-GLS, and KPSS. I estimate the regressions associated with these four tests with an intercept and a time trend.

In table 3, I report the results of unit root tests for all IT and non-IT countries. For most countries, the unit root test results vary across the tests; exceptions are Brazil, Hungary, South Africa, Estonia, Malaysia, and Singapore, for which all unit root test results are either stationary or non-stationary. These mixed results are due to small sample periods. Since the majority of the unit root test results are mixed, I specify a baseline model. The variables for which all unit root test results show non-stationarity are first differenced or second differenced; otherwise variables are included in levels. Starr (2005) specifies the same baseline model to get the correct order of integration. However, if I use this approach, there is always the possibility that variables in the level might be non-stationary because the variables for which test results do not consistently show non-stationarity are included as level. So, the correct order of integration remains uncertain. To address this problem, I use a Toda-Yamamoto based Granger causality test. Because the order of integration of variables is uncertain, the Toda-Yamamoto method considers the highest order of integration of the variables. For this reason, the Toda-Yamamoto based Granger causality test is robust to the order of integration of the variables.

Suppose the true lag length of the VAR is $p$ and the highest order of integration of variables in the VAR model is $k$. The Toda-Yamamoto method estimates the VAR with $p+k$ lags. Thus, I estimate the VAR model for all IT and non-IT countries with the number of lags that is the sum of the true lag length and the maximum order of integration. For cross country analysis, researchers like Hafer and Kutan (1997) and Starr (2005) fix the number of lags for their VARs. They do not vary the number of lags across the model because doing so makes comparing the results difficult. I do not fix lags in this way because such cross-country comparisons are not essential in this study. Moreover, fixing the number of lags restricts our ability to add lags in order to eliminate residual serial correlation.

Table 3. Unit root tests

\begin{tabular}{llll}
\hline \multicolumn{1}{c}{ Country } & \multicolumn{1}{c}{ Variables } & Results from unit root tests & Differenced in the model \\
Inflation targeting & countries & & Yes \\
\hline Brazil & CPI, IPI, Interest rate, M1, M2 and Exchange rate & Consistently non-stationary & Yes \\
Canada & CPI, IPI, Interest rate, M1, M2 & Consistently non-stationary Stationary & No \\
& Exchange rate & by KPSS & Yes \\
Chile & CPI and Exchange rate & Consistently non-stationary & No \\
& IPI & Stationary by DF-GLS & No \\
& Interest rate & Stationary by KPSS & No \\
Columbia & M1 & Stationary by ADF test & Yes \\
& CPI, Interest rate and Exchange rate & Consistently non-stationary & No \\
& IPI & Stationary by ADF and KPSS & No \\
Czech Republic & Stationary by KPSS & No \\
& M1 & Stationary by ADF test & Yes \\
Hungary & CPI, M2 and Exchange rate & Consistently non-stationary & No \\
Mexico & IPI and Interest rate & Stationary by KPSS & Yes \\
& CPI, IPI, Interest rate, M1, M2 and Exchange rate & Consistently non-stationary & Yes \\
New Zealand & CPI, Interest rate, M2 and Exchange rate & Consistently non-stationary & No \\
& IPI and M1 & Stationary by DF-GLS & Yes \\
CPI, M2 and Exchange rate & Consistently non-stationary & No \\
Norway & IPI & Stationary by KPSS & No \\
& Interest rate & Stationary by ADF and KPSS & Yes \\
\hline
\end{tabular}




\begin{tabular}{|c|c|c|c|}
\hline \multirow[t]{4}{*}{ Peru } & CPI & Stationary by P-P & No \\
\hline & IPI, Interest rate and M1 & Stationary by KPSS & No \\
\hline & M2 & Stationary by ADF & No \\
\hline & Exchange rate & Consistently non-stationary & Yes \\
\hline \multirow[t]{2}{*}{ Philippines } & CPI, IPI and M1 & Consistently non-stationary & Yes \\
\hline & Interest rate, $\mathrm{M} 2$ and Exchange rate & Stationary by KPSS & No \\
\hline \multirow[t]{3}{*}{ Poland } & CPI, Interest rate and Exchange rate & Consistently non-stationary & Yes \\
\hline & IPI & Stationary by ADF & No \\
\hline & M2 & Stationary by KPSS & No \\
\hline South Africa & CPI, IPI, Interest rate, M1, M2 and Exchange rate & Consistently non-stationary & Yes \\
\hline \multirow[t]{2}{*}{ South Korea } & CPI, IPI, Interest rate and M1 & Consistently non-stationary & Yes \\
\hline & M2 and Exchange rate & Stationary by KPSS & No \\
\hline \multirow[t]{4}{*}{ Sweden } & CPI & Stationary by KPSS & No \\
\hline & IPI & Consistently non-stationary & Yes \\
\hline & Interest rate & Stationary by ADF, DF-GLS and KPSS & No \\
\hline & M3 and Exchange rate & Stationary by DF-GLS & No \\
\hline \multirow[t]{2}{*}{ Switzerland } & CPI, IPI, Interest rate and M2 & Stationary by KPSS & No \\
\hline & M1 and Exchange rate & Consistently non-stationary & Yes \\
\hline \multirow[t]{3}{*}{ United Kingdom } & CPI, IPI and Exchange rate & Consistently non-stationary & Yes \\
\hline & Interest rate & Stationary by KPSS & No \\
\hline & M1 & Stationary by DF-GLS & No \\
\hline \multirow[t]{2}{*}{ Austria } & CPI & Stationary by ADF & No \\
\hline & IPI, Interest rate, M1 and Exchange rate & Consistently non-stationary & Yes \\
\hline \multirow[t]{3}{*}{ Bolivia } & CPI, IPI, Interest rate and Exchange rate & Consistently non-stationary & Yes \\
\hline & M1 & Stationary by DF-GLS & No \\
\hline & M2 & Stationary by ADF & No \\
\hline \multirow[t]{2}{*}{ Denmark } & CPI & Stationary by KPSS & No \\
\hline & IPI, Interest rate, M1, M2 and Exchange rate & Consistently non-stationary & Yes \\
\hline Estonia & CPI, IPI, Interest rate, M1, M2 and Exchange rate & Consistently non-stationary & Yes \\
\hline \multirow[t]{2}{*}{ France } & CPI, IPI, Interest rate, M1 and Exchange rate & Stationary by KPSS & No \\
\hline & M2 & Consistently non-stationary & Yes \\
\hline \multirow[t]{2}{*}{ Germany } & CPI, M1, M2 and Exchange rate & Consistently non-stationary & Yes \\
\hline & IPI and Interest rate & Stationary by KPSS & No \\
\hline \multirow[t]{2}{*}{ Italy } & CPI, IPI, Interest rate and M2 & Consistently non-stationary & Yes \\
\hline & Exchange rate & Stationary by KPSS & No \\
\hline \multirow[t]{2}{*}{ Japan } & CPI, IPI, Interest rate and Exchange rate & Stationary by KPSS & No \\
\hline & M1 and M2 & Consistently non-stationary & Yes \\
\hline \multirow[t]{2}{*}{ Lithuania } & CPI, IPI, M1 and M2 & Consistently non-stationary & Yes \\
\hline & Interest rate and Exchange rate & Stationary by KPSS & No \\
\hline Malaysia & CPI, IPI, Interest rate, M1, M2 and Exchange rate & Consistently non-stationary & Yes \\
\hline \multirow[t]{2}{*}{ Netherlands } & $\mathrm{CPI}$ and Interest rate & Stationary by KPSS & No \\
\hline & IPI, M2 and Exchange rate & Consistently non-stationary & Yes \\
\hline \multirow[t]{2}{*}{ Portugal } & CPI, IPI and M2 & Consistently non-stationary & Yes \\
\hline & Interest rate, $\mathrm{M} 1$ and Exchange rate & Stationary by KPSS & No \\
\hline \multirow[t]{2}{*}{ Russia } & CPI, IPI and M2 & Stationary by KPSS & No \\
\hline & Interest rate and Exchange rate & Consistently non-stationary & Yes \\
\hline Singapore & CPI, IPI, Interest rate, M1, M2 and Exchange rate & Consistently non-stationary & Yes \\
\hline \multirow[t]{2}{*}{ Slovenia } & CPI, Interest rate, M1, M2 and Exchange rate & Consistently non-stationary & Yes \\
\hline & IPI & Stationary by KPSS & No \\
\hline Spain & $\mathrm{CPI}$ and Interest rate & Stationary by DF-GLS and KPSS & No \\
\hline & IPI, M1 and M2 & Consistently non-stationary & Yes \\
\hline & Exchange rate & Stationary by KPSS & No \\
\hline United States & CPI, IPI, M1, M2 and Exchange rate & Consistently non-stationary & Yes \\
\hline & Interest rate & Stationary by KPSS & No \\
\hline Venezuela & CPI & Stationary by DF-GLS & No \\
\hline & IPI & Stationary by KPSS & No \\
\hline & Interest rate, $\mathrm{M} 2$ and Exchange rate & Consistently non-stationary & Yes \\
\hline
\end{tabular}


Initially, I use the Akaike Information Criterion (AIC) to select the lag length for each country. Then, I examine the residuals and apply the LM test where the null hypothesis is no serial correlation. If I find evidence of serial correlation, I add lags until the serial correlation is eliminated. So, $k$ represents the total number of these lags.

In Table 4, I report the Toda-Yamamoto Granger causality test results for thirty-five countries. These test results reveal whether policy variables both individually or jointly can explain future movements of inflation. If both M1 and M2 money supply data are available for a country, I estimate two separate Toda-Yamamoto Granger causality tests; the first test includes inflation, M1, the interest rate and the exchange rate and the second test includes inflation, M2, the interest rate and the exchange rate. In Table 5, I report the p-values, which represent the significance of monetary policy variables on inflation. If the p-value of a policy variable is greater than 0.05 , I fail to reject the null hypothesis that the policy variable does not Granger cause inflation. I fail to reject this null hypothesis for the following countries: Bolivia, Chile, Czech Republic, Estonia, Hungary, Lithuania, Malaysia, Netherlands, Peru, Philippines, South Korea, and Sweden. On the other hand, I reject the null hypothesis for all other countries.

In table 5, I assign a dummy-variable value of one to a country if at least one or all policy variables of that country can explain future movements of inflation at the 5\% significance level. Otherwise, I assign a dummy-variable value of zero. Seven IT countries out of seventeen IT countries did not meet this precondition before adopting their IT framework; these countries are Chile, Czech Republic, Hungary, Peru, Philippines, South Korea, and Sweden.

Table 4. Estimation of Toda-Yamamoto Granger causalities (p-value represents the significance of monetary policy variables for price)

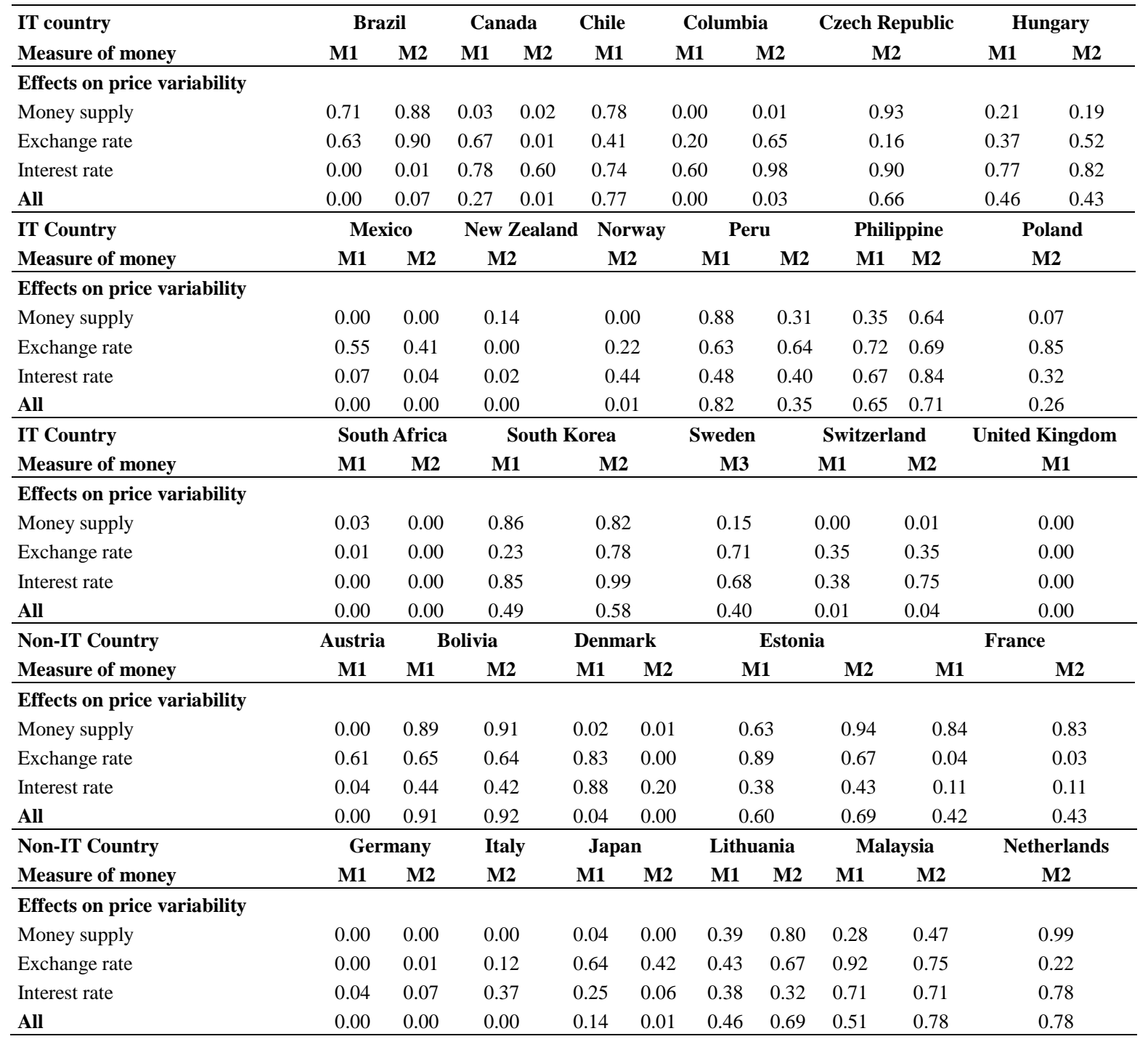




\begin{tabular}{lccccccccccccc}
\hline Non-IT country & \multicolumn{2}{c}{ Portugal } & \multicolumn{2}{c}{ Russia } & \multicolumn{2}{c}{ Singapore } & \multicolumn{2}{c}{ Slovenia } & \multicolumn{3}{c}{ Spain } & \multicolumn{4}{c}{ United States } & Venezuela \\
Measure of money & M1 & M2 & M2 & M1 & M2 & M1 & M2 & M1 & M2 & M1 & M2 & M2 \\
\hline Effects on price variability & & & & & & & & & & & & & \\
Money supply & 0.03 & 0.04 & 0.31 & 0.00 & 0.00 & 0.58 & 0.54 & 0.00 & 0.00 & 0.02 & 0.06 & 0.52 \\
Exchange rate & 0.84 & 0.89 & 0.32 & 0.83 & 0.00 & 0.12 & 0.16 & 0.00 & 0.01 & 0.01 & 0.02 & 0.03 \\
Interest rate & 0.90 & 0.93 & 0.01 & 0.71 & 0.00 & 0.68 & 0.99 & 0.00 & 0.00 & 0.00 & 0.00 & 0.09 \\
All & 0.28 & 0.31 & 0.06 & 0.00 & 0.00 & 0.57 & 0.03 & 0.00 & 0.00 & 0.00 & 0.00 & 0.00 \\
\hline
\end{tabular}

Table 5. Effects of monetary instruments on price variability

\begin{tabular}{|c|c|c|c|c|c|}
\hline \multirow[b]{2}{*}{ IT Country } & \multicolumn{5}{|c|}{ Effects of monetary instruments on price variability } \\
\hline & $\begin{array}{l}\text { Money supply } \\
\text { Yes=1 and } \mathrm{No}=0\end{array}$ & $\begin{array}{c}\text { Interest rate } \\
\text { Yes }=1 \text { and } \mathrm{No}_{0}=0\end{array}$ & $\begin{array}{c}\text { Exchange rate } \\
\text { Yes }=1 \text { and } \mathrm{No}=0\end{array}$ & $\begin{array}{l}\text { All policy instruments } \\
\text { Yes }=1 \text { and } \mathrm{No}=0\end{array}$ & $\begin{array}{l}\text { Did country meet this pre-condition? } \\
\text { Yes }=1 \text { and } N o=0\end{array}$ \\
\hline Brazil & 0 & 1 & 0 & 1 & 1 \\
\hline Canada & 1 & 0 & 0 & 1 & 1 \\
\hline Chile & 0 & 0 & 0 & 0 & 0 \\
\hline Columbia & 1 & 0 & 0 & 1 & 1 \\
\hline Czech Republic & 0 & 0 & 0 & 0 & 0 \\
\hline Hungary & 0 & 0 & 0 & 0 & 0 \\
\hline Mexico & 1 & 1 & 0 & 1 & 1 \\
\hline New Zealand & 0 & 1 & 1 & 1 & 1 \\
\hline Norway & 1 & 0 & 0 & 1 & 1 \\
\hline Peru & 0 & 0 & 0 & 0 & 0 \\
\hline Philippines & 0 & 0 & 0 & 0 & 0 \\
\hline Poland & 1 & 0 & 0 & 0 & 1 \\
\hline South Africa & 1 & 1 & 1 & 1 & 1 \\
\hline South Korea & 0 & 0 & 0 & 0 & 0 \\
\hline Sweden & 0 & 0 & 0 & 0 & 0 \\
\hline Switzerland & 1 & 0 & 0 & 1 & 1 \\
\hline \multirow[t]{2}{*}{ United Kingdom } & 1 & 1 & 1 & 1 & 1 \\
\hline & \multicolumn{5}{|c|}{ Effects of monetary instruments on price variability } \\
\hline $\begin{array}{l}\text { Non-IT } \\
\text { Country }\end{array}$ & $\begin{array}{c}\text { Money supply } \\
\text { Yes=1 and } \mathrm{No}=0\end{array}$ & $\begin{array}{c}\text { Interest rate } \\
\text { Yes }=1 \text { and } \mathrm{No}_{0}=0\end{array}$ & $\begin{array}{c}\text { Exchange rate } \\
\text { Yes }=1 \text { and } \mathrm{No}=0\end{array}$ & $\begin{array}{c}\text { All policy instruments } \\
\text { Yes }=1 \text { and } \mathrm{No}=0\end{array}$ & $\begin{array}{c}\text { ts Did country meet this pre-condition? } \\
\text { Yes=1 and No=0 }\end{array}$ \\
\hline Austria & 1 & 1 & 0 & 1 & 1 \\
\hline Bolivia & 0 & 0 & 0 & 0 & 0 \\
\hline Denmark & 1 & 0 & 1 & 1 & 1 \\
\hline Estonia & 0 & 0 & 0 & 0 & 0 \\
\hline France & 0 & 0 & 1 & 0 & 1 \\
\hline Germany & 1 & 1 & 1 & 1 & 1 \\
\hline Italy & 1 & 0 & 0 & 1 & 1 \\
\hline Japan & 1 & 1 & 0 & 1 & 1 \\
\hline Lithuania & 0 & 0 & 0 & 0 & 0 \\
\hline Malaysia & 0 & 0 & 0 & 0 & 0 \\
\hline Netherlands & 0 & 0 & 0 & 0 & 0 \\
\hline Portugal & 1 & 0 & 0 & 0 & 1 \\
\hline Russia & 0 & 1 & 0 & 1 & 1 \\
\hline Singapore & 1 & 0 & 0 & 1 & 1 \\
\hline Slovenia & 0 & 0 & 0 & 1 & 1 \\
\hline Spain & 1 & 1 & 1 & 1 & 1 \\
\hline United States & 1 & 1 & 1 & 1 & 1 \\
\hline Venezuela & 0 & 1 & 1 & 1 & 1 \\
\hline
\end{tabular}

\subsection{Effects of Preconditions of IT on the Successful Implementation of IT Frameworks}

To assess the effects of preconditions of IT on post-IT macroeconomic performance, I use the following five macroeconomic indicators as the dependent variable: output growth, the volatility of output growth, inflation, the volatility of inflation and an output-inflation variability ratio. I measure output growth as the quarterly growth of 
real GDP and I use the quarterly growth in the CPI as a measurement of inflation.

Table 6. Model specifications

\begin{tabular}{|c|c|c|c|}
\hline $\begin{array}{l}\text { Model } \\
\text { number }\end{array}$ & Method & Time period & Sample \\
\hline Model 1 & $\begin{array}{l}\text { Difference-in-difference } \\
\text { analysis }\end{array}$ & $\begin{array}{l}\text { Pre-period: } 5 \text { years before IT adoption and post-period: } 5 \\
\text { years from IT adoption years. }\end{array}$ & $\begin{array}{l}\text { Only inflation targeting countries } \\
\text { (total countries 17) }\end{array}$ \\
\hline Model 2 & $\begin{array}{l}\text { Difference-in-difference } \\
\text { analysis }\end{array}$ & $\begin{array}{l}\text { Pre-period: } 10 \text { years before IT adoption and post-period: } 10 \\
\text { years from IT adoption years. }\end{array}$ & $\begin{array}{l}\text { Only inflation targeting countries } \\
\text { (total countries 17) }\end{array}$ \\
\hline Model 3 & $\begin{array}{l}\text { Difference-in-difference } \\
\text { analysis }\end{array}$ & $\begin{array}{l}\text { Pre-period: } 5 \text { years before IT adoption/partition year and } \\
\text { post-period: } 5 \text { years from IT adoption /partition years. }\end{array}$ & $\begin{array}{l}\text { Both inflation and non-inflation } \\
\text { targeting countries (total countries 35) }\end{array}$ \\
\hline Model 4 & $\begin{array}{l}\text { Difference-in-difference } \\
\text { analysis }\end{array}$ & $\begin{array}{l}\text { Pre-period: } 10 \text { years before IT adoption/partition year and } \\
\text { post-period: } 10 \text { years from IT adoption /partition years. }\end{array}$ & $\begin{array}{l}\text { Both inflation and non-inflation } \\
\text { targeting countries (total countries 23) }\end{array}$ \\
\hline Model 5 & $\begin{array}{l}\text { Output-inflation } \\
\text { variability ratio }\end{array}$ & $\begin{array}{l}\text { Pre-period: } 5 \text { years before IT adoption/partition year and } \\
\text { post-period: } 5 \text { years from IT adoption /partition years. }\end{array}$ & $\begin{array}{l}\text { Both inflation and non-inflation } \\
\text { targeting countries (total countries 35) }\end{array}$ \\
\hline Model 6 & $\begin{array}{l}\text { Output-inflation } \\
\text { variability ratio }\end{array}$ & $\begin{array}{l}\text { Pre-period: } 10 \text { years before IT adoption/partition year and } \\
\text { post period: } 10 \text { years from IT adoption /partition years. }\end{array}$ & $\begin{array}{l}\text { Both inflation and non-inflation } \\
\text { targeting countries (total countries 23) }\end{array}$ \\
\hline
\end{tabular}

In Table 6, I report the model specifications for our regression analyses. Models 1 and 2 include seventeen IT countries only. The period for model 1 is five years before and after IT adoption. The period for model 2 is ten years before and after IT adoption. Models 3 and 4 include seventeen IT countries and eighteen non- IT countries. The periods for models 3 and 4 are five years before and after IT adoption and ten years before and after IT adoption respectively. In models 5 and 6 , I use a measure of the output-inflation volatility ratio as a dependent variable. More specifically, the dependent variable in models 5 and 6 is the ratio of pre- to- post-IT adoption output-inflation variability. Both models 5 and 6 include seventeen IT and eighteen non- IT countries. The sample period for models 5 and 6 is five years before and after IT adoption and ten years before and after IT adoption, respectively (Note 10).

\subsubsection{Difference-in-Difference Method}

In Table 7, I represent the effects of preconditions of IT on post-IT output growth and volatility of output growth. According to table 7, there is no significant relationship between output in IT countries and the preconditions of IT. The interaction term of two preconditions of IT has a positive relationship with growth in IT countries, but it is not statistically significant. A statistically significant negative relationship exists between post-IT output growth and pre-IT output growth. Thus, IT countries with initial higher output growth have lower output growth after adopting IT. This result is consistent with both models 1 and 2 .

Table 7. Regression results for growth and growth volatility without control group (difference-in-difference method)

\begin{tabular}{|c|c|c|c|c|}
\hline \multirow[t]{2}{*}{ Independent variables } & \multicolumn{2}{|c|}{ Growth } & \multicolumn{2}{|c|}{ Growth volatility } \\
\hline & Model 1 & Model 2 & Model 1 & Model 2 \\
\hline \multirow[t]{2}{*}{ Initial condition } & $-0.99 *$ & $-0.82 *$ & $-0.84^{*}$ & $-0.95 *$ \\
\hline & $(0.21)$ & $(0.15)$ & $(0.12)$ & $(0.12)$ \\
\hline \multirow[t]{2}{*}{ CBI } & 0.12 & 1.50 & 0.22 & $1.74 * * *$ \\
\hline & $(4.08)$ & $(2.40)$ & $(1.44)$ & $(0.92)$ \\
\hline \multirow[t]{2}{*}{ PSR (Dummy) } & -1.78 & -0.65 & 0.92 & 0.92 \\
\hline & $(2.17)$ & $(1.39)$ & $(1.11)$ & $(0.55)$ \\
\hline \multirow[t]{2}{*}{ CBI*PSR } & 0.59 & -0.39 & -0.98 & -1.84 \\
\hline & $(3.87)$ & $(3.02)$ & $(1.77)$ & $(1.30)$ \\
\hline \multirow[t]{2}{*}{ Constant } & 3.65 & $2.47 * * *$ & 0.87 & $1.07 *$ \\
\hline & $(2.11)$ & $(1.26)$ & $(0.98)$ & $(0.29)$ \\
\hline Total observations & 17 & 17 & 17 & 17 \\
\hline R-squared & 0.77 & 0.67 & 0.82 & 0.90 \\
\hline
\end{tabular}

Note. Figures in parentheses are Huber-White robust standard errors HC1.

$*$ indicates $1 \%$ level of significance, $* * 5 \%$ level of significance and $* * * 10 \%$ level of significance.

Moreover, the preconditions of IT and the interaction term of preconditions have no statistically significant effect 
on the volatility of output growth for model 1 . However, according to model 2 , there is a positive relationship between CBI and output growth volatility. Additionally, a statistically significant negative relationship exists between the post-IT volatility of output growth and pre-IT volatility of output growth.

According to Table 8 , a statistically significant negative relationship exists between post-IT inflation and pre-IT inflation. Thus, IT countries with high inflation before IT adoption experience low inflation after IT adoption. In addition, IT countries that met both preconditions (both CBI and PSR) before adopting IT reduce inflation by 11.55 points more than IT countries that did not meet both preconditions in the short-run (model 1). However, preconditions of IT do not have any statistically significant effect on inflation for model 2 . The preconditions of IT do not have any significant relationship with inflation volatility for both models 1 and 2. However, inflation volatility is negatively related to initial inflation volatility for both models 1 and 2 . It is statistically significant at $1 \%$.

Table 8. Regression results for inflation and inflation volatility without control group (difference-in-difference method)

\begin{tabular}{lcccc}
\hline Independent variables & \multicolumn{2}{c}{ Inflation } & \multicolumn{2}{c}{ Inflation volatility } \\
\cline { 2 - 5 } & Model 1 & Model 2 & Model 1 & Model 2 \\
\hline Initial condition & $-0.54^{*}$ & $-0.96^{*}$ & $-0.80^{*}$ & $-0.98^{*}$ \\
& $(0.08)$ & $(0.03)$ & $(0.13)$ & $(0.01)$ \\
CBI & 0.95 & 4.16 & 1.69 & 2.61 \\
& $(3.41)$ & $(3.76)$ & $(3.17)$ & $(2.23)$ \\
PSR (Dummy) & 2.91 & 3.53 & 1.02 & 1.84 \\
& $(2.61)$ & $(2.78)$ & $(1.58)$ & $(1.36)$ \\
CBI*PSR & $-9.99^{* *}$ & -7.78 & -1.91 & -4.15 \\
& $(4.81)$ & $(5.90)$ & $(3.48)$ & $(3.02)$ \\
Constant & -0.03 & 1.14 & 0.25 & 0.31 \\
Total observations & $(2.08)$ & $(1.82)$ & $(1.41)$ & $(1.02)$ \\
R-squared & $\mathbf{1 7}$ & $\mathbf{1 7}$ & $\mathbf{1 7}$ & $\mathbf{1 7}$ \\
\hline
\end{tabular}

Note. Figures in parentheses are Huber-White robust standard errors $\mathrm{HC} 1$.

$*$ indicates $1 \%$ level of significance, $* * 5 \%$ level of significance and $* * * 10 \%$ level of significance.

In model 3 and model 4, I include eighteen non-IT countries as a control group. Table 9 and Table 10 report the effects of preconditions of IT on macroeconomic performance with the control group included. According to table 9 , countries that had a stable and predictable relationship between monetary instruments and inflation before IT adoption experienced a reduction in growth by 2.18 points more in the short-run than the growth of countries that did not meet this precondition. However, this negative relationship is not statistically significant for model 4. I also find that initial growth is negatively related to growth for both model 3 and model 4. IT dummy variable has a negative sign, but it is not statistically significant. The preconditions of IT and their interaction terms with IT are not significantly related to growth volatility. Again, I find the IT dummy is negatively related to growth volatility, but it is not statistically significant. The relationship between growth volatility and initial growth volatility is negative, but this relationship is only statistically significant for model 3 .

A statistically significant negative relationship exists between inflation and IT countries that met all the preconditions before adopting IT for model 1 . For model 3, the same result holds. Likewise, this relationship is not significant for model 4 . This result likely reflects the fact that IT countries who met all the preconditions before adopting IT can more successfully implement IT framework after IT adoption. One of the explanations is that these countries have a higher degree of CBI, and their money, capital, and foreign exchange markets are very responsive to policy decisions. On the other hand, IT countries that did not meet these preconditions before adopting IT requires time to ensure CBI and responsive capital, money and foreign exchange markets. As a result, IT countries who met preconditions before adopting IT can reduce inflation more than other IT countries in the short-run ( 5 years period) but not in the long-run (10 years period). Post-IT inflation and pre-IT inflation are significantly negatively related in both models 3 and 4 . Similarly, a statistically significant relationship exists between post-IT inflation volatility and pre-IT inflation volatility for both models 3 and 4 . However, preconditions of IT and their interaction terms with IT have no relationship with inflation volatility. I find that IT dummy variable has no relationship to either inflation or inflation volatility. 
Table 9. Regression results for growth and growth volatility with control group (difference-in-difference method)

\begin{tabular}{lcccc}
\hline Independent variables & & Growth & \multicolumn{2}{c}{ Growth volatility } \\
\cline { 2 - 5 } & Model 3 & Model 4 & Model 3 & Model 4 \\
\hline Initial condition & $-0.83^{*}$ & $-0.74 *$ & $-0.75^{* *}$ & $-0.50^{* * *}$ \\
& $(0.15)$ & $(0.13)$ & $(0.29)$ & $(0.27)$ \\
CBI & 1.17 & -1.36 & -3.63 & 3.94 \\
& $(2.24)$ & $(1.51)$ & $(2.73)$ & $(6.52)$ \\
PSR (Dummy) & $-2.06^{* * *}$ & -0.48 & -0.50 & 1.16 \\
& $(1.11)$ & $(0.45)$ & $(1.49)$ & $(2.48)$ \\
IT (Dummy) & -0.48 & -1.72 & -3.28 & 0.68 \\
& $(2.72)$ & $(1.41)$ & $(2.72)$ & $(3.84)$ \\
CBI*IT & -1.83 & 2.77 & 3.88 & -4.54 \\
& $(4.58)$ & $(2.83)$ & $(3.14)$ & $(6.93)$ \\
PSR*IT & 0.20 & -0.18 & 1.64 & 0.26 \\
CBI*PSR*IT & $(2.28)$ & $(1.50)$ & $(1.60)$ & $(2.73)$ \\
Constant & 0.54 & -0.28 & -1.27 & -2.48 \\
Total observations & $(3.67)$ & $(3.19)$ & $(2.11)$ & $(2.64)$ \\
R-squared & $4.05 * * *$ & $3.99 *$ & 3.85 & -0.01 \\
\hline
\end{tabular}

Note. Figures in parentheses are Huber-White robust standard errors HC1.

$*$ indicates $1 \%$ level of significance, $* * 5 \%$ level of significance and $* * * 10 \%$ level of significance.

Table 10. Regression results for inflation and inflation volatility with control group (difference-in-difference method)

\begin{tabular}{lcccc}
\hline Independent variables & \multicolumn{2}{c}{ Inflation } & \multicolumn{2}{c}{ Inflation volatility } \\
\cline { 2 - 5 } & Model 3 & Model 4 & Model 3 & Model 4 \\
\hline Initial condition & $-0.58^{*}$ & $-0.85^{*}$ & $-0.84^{*}$ & $-0.98^{*}$ \\
& $(0.03)$ & $(0.11)$ & $(0.03)$ & $(0.01)$ \\
CBI & -0.95 & 15.05 & 0.77 & $10.16^{* *}$ \\
& $(1.69)$ & $(11.94)$ & $(0.59)$ & $(4.01)$ \\
PSR (Dummy) & 0.27 & 1.69 & 0.30 & 0.99 \\
& $(0.81)$ & $(3.48)$ & $(0.34)$ & $(1.41)$ \\
IT (Dummy) & -0.67 & 6.40 & 0.33 & 2.84 \\
& $(2.32)$ & $(6.55)$ & $(1.41)$ & $(2.25)$ \\
CBI*IT & 2.44 & -14.73 & 0.95 & -7.63 \\
& $(4.08)$ & $(13.03)$ & $(3.08)$ & $(4.63)$ \\
PSR*IT & 2.73 & 4.81 & 0.65 & 1.03 \\
& $(2.71)$ & $(5.31)$ & $(1.59)$ & $(2.05)$ \\
CBI*PSR*IT & $-9.83^{* *}$ & -18.19 & -1.60 & -4.54 \\
Constant & $(4.69)$ & $(12.79)$ & $(3.48)$ & $(3.90)$ \\
Total observations & 0.59 & -4.56 & 0.04 & -4.68 \\
R-squared & 1.18 & $(6.08)$ & $(0.38)$ & $(3.12)$ \\
\hline
\end{tabular}

Note. Figures in parentheses are Huber-White robust standard errors HC1.

$*$ indicates $1 \%$ level of significance, $* * 5 \%$ level of significance and $* * * 10 \%$ level of significance.

\subsubsection{Output-Inflation Variability Ratio}

The average standard deviation of output growth rate for IT countries for five years after IT adoption is 1.77 which is -1.01 points less than the average standard deviation for five years before IT adoption. On the other hand, the average standard deviation of inflation for IT countries for five years after IT adoption is 2.06, which is -1.90 points less as compared to the average standard deviation of inflation for five years before IT adoption. So both inflation variability and output variability decrease, but inflation variability decrease more than output variability. For this reason, regression results based on our difference-in-difference method may show that both inflation variability and output variability are decreasing for IT countries (models 1 to 4). 
Table 11. Regression results for the trade-off between output-inflation variability with control group

\begin{tabular}{lcc}
\hline Independent variables & Output-inflation trade-off \\
\cline { 2 - 3 } CBI & Model 5 & Model 6 \\
& $2.57^{* * *}$ & $-3.90^{* *}$ \\
PSR (Dummy) & $(1.29)$ & $(1.60)$ \\
& $0.99^{* * *}$ & 0.12 \\
IT (Dummy) & $(0.54)$ & $(0.41)$ \\
& $-21.51^{* * *}$ & -5.98 \\
CBI*IT & $(11.35)$ & $(4.18)$ \\
& $67.73^{*}$ & 16.08 \\
PSR*IT & $(29.23)$ & $(11.94)$ \\
& $34.27 * * *$ & -5.28 \\
CBI*PSR*IT & $(16.26)$ & $(5.11)$ \\
& $-61.61^{* * *}$ & -11.49 \\
Developing & $(29.04)$ & $(10.92)$ \\
Developing*IT & $-1.01 * * *$ & -0.07 \\
Constant & $(0.50)$ & $(0.60)$ \\
Total observations & $-16.60^{* *}$ & -2.51 \\
R-squared & $(9.22)$ & $(2.68)$ \\
\hline
\end{tabular}

Note. Figures in parentheses are Huber-White robust standard errors HC1.

$*$ indicates $1 \%$ level of significance, $* * 5 \%$ level of significance and $* * * 10 \%$ level of significance.

As mentioned earlier, Cecchetti and Ehrmann (2000) argue that it is important to use the ratio of pre and post output-inflation variability to capture any change in a central bank's aversion to inflation variability (around the central bank's inflation target). In Table 11, I report the effects of preconditions of IT on the implementation of IT both in the short run and in the long-run using output-inflation variability ratio (models 5 and 6 ). I find that the ratio of output-inflation variability before IT adoption in the short-run (model 5) is less than the ratio of output-inflation variability after IT adoption. Thus for IT countries, output variability is more relative to inflation variability after these countries adopt IT.

Meeting any one of two preconditions of IT is positively related to the output-inflation variability ratio (see Table 11 model 5). Thus, these countries have more inflation variability relative to output variability. On the other hand, IT countries that met all the preconditions of IT before IT adoption have higher output variability relative to inflation variability, as compared to other IT and non-IT countries. Additionally, developing IT countries have higher output variability relative to inflation variability than other IT and non-IT countries. However, only CBI is negatively related to the output-inflation trade-off in the long-run, and it is statistically significant at $1 \%$ level. Thus, countries with high CBI before IT adoption have higher output variability relative to inflation variability as compared to countries with low CBI before IT adoption. I do not find any relationship between IT countries that met all preconditions and the output-inflation variability ratio in the long run (see Table 11 model 6).

So, I find that in the short-run, IT countries that met all preconditions before IT adoption have greater output variability relative to inflation variability than other countries. This implies that IT countries that met all the preconditions before IT adoption can implement IT more effectively than IT countries that did not meet all preconditions before IT adoption. But IT countries that met all preconditions before IT adoption do not have any relative advantage in the long-run. Because IT countries that did not meet all preconditions before IT adoption can meet all these preconditions eventually - that is, in the long-run.

\section{Conclusion}

There is a significant amount of literature that studies IT frameworks and the importance of such frameworks on macroeconomic performance. One of the potential advantages of IT is that it ensures price stability in an economy, and it does so by increasing the credibility of the central bank. Both stable inflation and high central bank credibility reduce the output loss related to disinflation policies. Thus, IT can achieve low and stable inflation and strong output growth. There are several preconditions of an IT framework that a country needs to fulfill before adopting IT. To fulfill these preconditions of inflation targeting, a country needs resources to ensure it meets specific institutional and technical requirements. A large literature emphasizes the importance of satisfying preconditions for the successful implementation of IT. But Batini and Laxton (2006) show that the fulfillment of preconditions of IT before adopting IT is not essential. 
This study addresses the debate, which is important, in part, because many developing countries want to adopt an IT framework to ensure low and stable inflation. Meanwhile, the international donor agencies recommend these developing countries to satisfy the preconditions of IT before adopting IT frameworks. However, developing countries require massive investment to satisfy all preconditions of IT before IT adoption. Thus, the results of this study will help developing countries whether they adopt IT frameworks.

In this study, I use two preconditions of IT frameworks. These are central bank independence and the existence of a stable and predictable relationship between monetary instruments and inflation before IT adoption. I use Cukierman's CBI index to measure the degree of central bank independence of thirty-five countries before IT adoption. I code a dummy variable for the second preconditions of IT by using the Toda-Yamamoto Granger causality test.

To assess the effects of preconditions of IT on post-IT macroeconomic performance, I use the difference-in-difference method to estimate the regression. I find that fulfillment of preconditions before IT adoption does not have significant effects on output growth and output growth volatility both in the short-run and in the long-run. On the other hand, I find that countries that met preconditions before IT adoption experience lower inflation in the short-run as compared to other countries. However, I do not find relationships between the fulfillment of preconditions before IT adoption and inflation volatility both in the short-run and in the long-run.

Cecchetti and Ehrmann (2000) argue that both inflation and output variability decrease after adopting IT but inflation variability decreases more than output variability. So, the regression results based on the difference-in-difference method may show that both inflation variability and output variability are decreasing for IT countries. For this reason, I use the ratio of pre- to- post output-inflation variability as a dependent variable to estimate the effects of preconditions of IT on macroeconomic performance afterward. I find that the output-inflation variability ratio method is better than the difference-in-difference method at identifying the effects of preconditions on post IT macroeconomic performance. By using the output-inflation variability ratio as the dependent variable, I find that the fulfillment of both preconditions before IT adoption ensures more effective implementation of IT framework than countries that did not meet both preconditions before IT adoption. However, countries that met all preconditions before IT adoption do not have an advantage over other IT countries in the long-run. IT countries that did not meet preconditions before IT adoption can do so after they adopt IT. Once these countries fulfill all these preconditions of inflation targeting, they can also achieve low and stable inflation. So, this paper suggests that fulfillment of all preconditions before IT adoption can ensure low and stable inflation and successful implementation of IT only in the short-run.

\section{References}

Agenor, P. (2002). Monetary Policy under Flexible Exchange Rates: An Introduction to Inflation Targeting. In N. Loayza, R. Soto, N. Loayza, \& K. Schmidt-Hebbel, (Eds.), Ten Years of Inflation Targeting: Design, Performance and Challenges. Central Bank of Chile.

Aliyu, S., \& Englama, A. (2009). Is Nigeria Ready for Inflation Targeting. Journal of Money, Investment and Banking, 11, 27-44.

Bakradze, G., \& Billmeier, A. (2007). Inflation Targeting in Georgia: Are We There Yet? IMF Working Paper, 2007-193. https://doi.org/10.5089/9781451867572.001

Ball, L., \& Sheridan, N. (2005). Does Inflation Targeting Matter? NBER Studies in Business Cycles, 32. Retrieved from https://www.nber.org/papers/w9577.pdf

Batini, N., \& Laxton, D. (2006). Under What Conditions Can Inflation Targeting Be Adopted? The Experience of Emerging Markets. $9^{\text {th }}$ Annual Conference of the Central Bank of Chile, Chile. Retrieved from https://ideas.repec.org/p/chb/bcchwp/406.html

Carare, A., Schaechter, A., Stone, M., \& Zelmer, M. (2002). Establishing Initial Conditions in Support of Inflation Targeting. Working Paper No. 2002-102, IMF. Retrieved from https://www.imf.org/external/pubs/ft/wp/2002/wp02102.pdf

Cecchetti, S., \& Ehrmann, M. (2000). Does inflation targeting increase output volatility? An international comparison of policymakers' preference and outcomes. Working paper No. 2000-69, Central Bank of Chile. https://doi.org/10.3386/w7426

Cecchetti, S., Margaret, M., \& Gabriel, P. (2002). Policymakers' Revealed Preferences and the Output-Inflation Variability Trade-Off: Implications for the European System of Central Banks. The Manchester School, 70, 596-618. https://doi.org/10.1111/1467-9957.00302 
Christoffersen, P., Sløk, T., \& Wescott, R. (2001). Is Inflation Targeting Feasible in Poland? The Economics of Transition. The European Bank for Reconstruction and Development, 9(1), 153-174. https://doi.org/10.1111/1468-0351.00071

Crowe, C., \& Meade, E. (2007). The Evolution of Central Bank Governance around the World. Journal of Economic Perspectives, 21, 69-90. https://doi.org/10.1257/jep.21.4.69

Cukierman, A., Webb, S., \& Neyapti, B. (1992). Measuring the Independence of Central Banks and Its Effect on Policy Outcomes. World Bank Economic Review, 6, 353-398. https://doi.org/10.1093/wber/6.3.353

Debelle, G. (1999). Inflation Targeting and Output Stabilization. Research Discussion Paper No. 4, Reserve Bank of Australia.

Debelle, G. (2001). The Case for Inflation Targeting in East Asian Countries. Paper Prepared for the Conference on Future Directions in Monetary Policy in Ease Asia, Reserve Bank of Australia, July.

Dejong, D., Nankervis, J., Savin, N. E., \& Whiteman, C. (1992). Integration Versus Trend Stationarity in Time Series. Econometrica, 60(2), 423-33. https://doi.org/10.2307/2951602

Dreher, A., Sturm, J., \& Haan, J. (2008). Does High Inflation Cause Central Bankers to Lose Their Job? Evidence Based on a New Data Set. European Journal of Political Economy, 24, 778-87. https://doi.org/10.1016/j.ejpoleco.2008.04.001

Eichengreen, B., Masson, P., Savastano, M., \& Sharma, S. (1999). Transition Strategies and Nominal Anchors on the Road to Greater Exchange Rate Flexibility. Essays in International Economics, No. 213. Department of Economics, Princeton University.

Eijiffinger, S., \& Geraats, P. (2006). How Transparent are Central Banks? European Journal of Political Economy, 22(1),1-21. https://doi.org/10.1016/j.ejpoleco.2005.09.013

Gemayel, E., Jahan, S., \& Peter, A. (2011). What Can Low-Income Countries Expect from Adopting Inflation Targeting? IMF Working Paper No. 276, IMF.

Goodhart, C. (2010). The Political Economy of Inflation Targets: New Zealand and the U.K. In L. Robert (Ed.), Canadian Policy Debates and Case Studies in Honour of DavidLaidler (pp. 171-214). Palgrave Macmillian. https://doi.org/10.1057/9780230274303_7

Hagen, J., \& Neuman, M. (2002). Does Inflation Targeting Matters? Federal Reserve Bank of St. Louis Review, 84(4), 127-148. https://doi.org/10.20955/r.84.127-148

Islam, M. S., \& Meerza, S. I. A. (2013). Trade, foreign direct investment and economic growth linkages in selected South Asian countries. In S. Ahmed (Ed.), Foreign Direct Investment, Trade and Economic Growth: Exploring Challenges and Opportunities (pp. 101-112). Routledge, New Delhi. https://www.taylorfrancis.com/books/e/9781315816203/chapters/10.4324/9781315816203-13

Islam, M., \& Uddin, M. (2011). Inflation Targeting as the Monetary Policy Framework: Bangladesh Perspective. Economia Seria Management, 14(1), 106-119.

Jacome, L., \& Vazquez, F. (2005). Any Link Between Central Bank Independence and Inflation? Evidence from Latin America and the Caribbean. Working paper No.75, IMF. https://doi.org/10.5089/9781451860948.001

Khan, M. (2003). Current Issues in the Design and Conduct of Monetary Policy. Working Paper No. 56, IMF. https://doi.org/10.5089/9781451847727.001

Meerza, S. I. A. (2012a). Exchange Rate Determination of Bangladesh: A Cointegration Approach. Journal of Economic Cooperation and Development, 33(3), 81-96. Retrieved from https://www.sesric.org/pdf.php?file=ART12060301-2.pdf

Meerza, S. I. A. (2012b). Causal Links between Trade, Foreign Direct Investment and Economic Growth for Bangladesh. Working Paper, South Dakota State University. https://ideas.repec.org/p/sda/workpa/12012.html

Mishkin, F. (2000). From Monetary Targeting to Inflation Targeting: Lessons from the Industrialized Countries. Bank of Mexico Conference, Mexico City, Nov 14-15. https://doi.org/10.1596/1813-9450-2684

Mishkin, F. (2007). Inflation Targeting: True Progress or Repackaging of an Old Idea? Swiss National Bank, 1907-2007, pp. 599-623.

Miskhin, F., \& Schmidt, K. (2007). Does Inflation Targeting Make a Difference? Working Paper No. 12786, National Bureau of Economic Research. https://doi.org/10.3386/w12876 
Mollick, A., Cabral, R., \& Carneiro, F. (2011). Does Inflation Targeting Matter for Output Growth? Evidence from Industrial and Emerging Economies. Journal of Policy Modeling, 33, 537-551. https://doi.org/10.1016/j.jpolmod.2011.03.010

Polillo, S., \& Guillén, M. (2005). Globalization Pressures and the State: The Worldwide Spread of Central Bank Independence. American Journal of Sociology, 110(6), 1764-1802. https://doi.org/10.1086/428685

Siklos, P. (2008). No Single Definition of Central Bank Independence is Right for All Countries. European Journal of Political Economy, 4(4), 802-816. https://doi.org/10.1016/j.ejpoleco.2008.07.004

Starr, M. (2005). Does Money Matters in the CIS? Effects of Monetary Policy on Output and Prices. Journal of Comparative Econ., 441-461. https://doi.org/10.1016/j.jce.2005.05.006

Toda, H. Y., \& Yamamoto, T. (1995). Statistical Inferences in Vector Autoregressions with Possibly Integrated Processes. Journal of Econometrics, 66(1-2), 225-50. https://doi.org/10.1016/0304-4076(94)01616-8

Truman, E. (2003). Inflation Targeting in the World Economy. Institute for International Economics, Washington, D.C.

Tutar, E. (2002). Inflation Targeting in Developing Countries and Its Applicability to the Turkish Economy. MS Thesis, Virginia Polytechnic Institute and State University.

\section{Notes}

Note 1. I follow IMF's list of developed and developing countries. According to IMF, there are thirty-five developed countries and one hundred sixty developing countries.

Note 2. One of the approaches to get information about preconditions of IT is to use survey method. Surveying the central bank gives information about institutional independence and technical structure of central bank before adopting IT along with all other preconditions. Batini and Laxton (2006) survey twenty one central banks of IT countries and ten central banks of non-IT countries in order to determine the effects of preconditions of inflation targeting. However, I do not follow the survey method because surveying different central banks is time consuming and costly.

Note 3. I use the Hodrick-Prescott filter to estimate the variability of output. The variability of output represents the average squared deviation of log output from the trend. The variability of inflation represents the average squared deviation of inflation from two percent inflation rate.

Note 4. Monthly and quarterly data for Bolivia, Estonia, Lithuania, Russia, Singapore, Slovenia and Venezuela do not exist before 1995. However, annual data for these countries do exist before 1995. So, I partition these six non-IT countries at 2000 .

Note 5. The sample period of Czech Republic and New Zealand are four years and five years before the IT adoption year respectively.

Note 6. The sample period for Lithuania and Singapore is four years before the partition year. On the other hand, the sample period for Venezuela is five years before the partition year.

Note 7. Several studies (e.g., Starr, 2005; Islam \& Meerza, 2013; and Meerza, 2012 a\&b) used the M1 money supply, the M2 money supply, the interest rate, and the exchange rate as monetary policy instruments

Note 8. I collect M2 money supply of Czech Republic and M2 money supply of New Zealand from OECD and Reserve Bank of New Zealand respectively.

Note 9. The monthly data for M1 and M2 money supply of Sweden for required sample period are not available. So, I include only M3 money supply in VAR for Sweden.

Note 10. The exception of this approach is the case of Brazil. The IT adopting date of Brazil is 1999. So, the sample period five years pre adoption ranges from 1994 to 1998; and the sample period ten year pre adoption ranges from 1989 to 1998. The average annual inflation rate for Brazil from 1989 to 1995 was about 1404.68\%. After 1996, the average annual inflation rate for Brazil fell below 50\%. I do not include high inflation periods, rather I use the sample period 1996-1998 as the pre-IT adoption period.

\section{Copyrights}

Copyright for this article is retained by the author(s), with first publication rights granted to the journal.

This is an open-access article distributed under the terms and conditions of the Creative Commons Attribution license (http://creativecommons.org/licenses/by/4.0/). 